\title{
Mentally ill and addicted offenders and their treatment in Nazi
} Germany Andreas Spengler*1 and Michael van der Haar²

Address: ${ }^{1}$ Nds. Landeskrankenhaus Wunstorf, Südstr.25, D 31515 Wunstorf, Germany and 2Fachabteilung Bad Rehburg, Friedrich-Stolberg-Allee 5, 31547 Bad Rehburg, Germany

* Corresponding author

from WPA Thematic Conference. Coercive Treatment in Psychiatry: A Comprehensive Review

Dresden, Germany. 6-8 June 2007

Published: 19 December 2007

BMC Psychiatry 2007, 7(SuppI I):S95 doi:10.1 186/147I-244X-7-SI-S95

This abstract is available from: http://www.biomedcentral.com/I47I-244X/7/SI/S95

(C) 2007 Spengler and van der Haar; licensee BioMed Central Ltd.

Mentally ill and addicted offenders are a small, but mostly ignored group of victims. The main program of Nazi mass murder, the so called T4-action captured these patients without exception. 1. This contribution will abstract shortly the organization and structures of the T4-action. 2. Short case histories of mentally ill or addicted offenders will be presented. They originate from the former "Heilund Pflegeanstalt Wunstorf", and will illustrate commitment and treatment of this group in German mental institutions, and follow their registration and deportation to killing centers in 1939-1941. Data were extracted from patient's records, public record office, Lower Saxonia. 